Volume 1, No. 3, September - December 2016 ISSN: 2503-4235 (p); 2503-4243 (e)

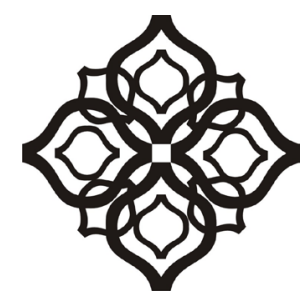

Shirkah

Journal of Economics and Business 


\section{Shirkah}

\section{Journal of Economics and Business \\ Vol. 1, No. 3, September-December 2016 \\ ISSN: 2503-4235 (p); 2503-4243 (e)}

\section{Editor in Chief}

Sri Walyoto

\section{Editorial Boards}

Abu Umar Faruq Ahmad, UBD School of Business and Economics, Brunei Darussalam

Amelia Fauzia, Asia Research Institute, National University of Singapore, Singapore

Cedomir Nestorovic, ESSEC Business School Asia Pacific, Singapore

Dwi Condro Triono, Faculty of Islamic Economics and Business, IAIN Surakarta, Indonesia

Fahmy Radhi, Faculty of Economics and Business Universitas Gadjah Mada, Yogyakarta, Indonesia

Hasan Basri, Syiah Kuala University, Aceh, Indonesia

Jaka Sriyana, Faculty of Economics, Universitas Islam Indonesia, Yogyakarta, Indonesia

Johan Fischer, Department of Social Sciences and Business Roskilde University, Denmark

Masudul Alam Choudhury, Postgraduate Program in Islamic Economics and Finance, Trisakti University, Jakarta, Indonesia and the College of Economics and Political Science (CEPS) in Sultan Qaboos University (SQU), Oman

M. Falik Isbah, School of Humanities and Social Science, University of New South Wales, Australia

M. Ishaq Bhatti, La Trobe Business School Department of Economics and Finance La Trobe University, Australia

Nunung Nurul Hidayah, Aston Business School, Aston University, Birmingham, United Kingdom

Najib Kailani, Pascasarjana, Universitas Islam Negeri (UIN) Sunan Kalijaga, Yogyakarta, Indonesia

Shaikh M Ghazanfar, Departement of Economics, University of Idaho, Russian Federation 
Managing Editors

M. Endy Saputro

M. Zainal Anwar

\section{Assistant to Editor}

Supriyanto

Shirkah Journal of Economics and Business is a peer-reviewed journal published three times a year (January-April, May-August and September-December) by Faculty of Islamic Economics and Business, Institut Agama Islam Negeri (IAIN/ State Institute for Islamic Studies) Surakarta Central Java, Indonesia. The main objective of Shirkah is to offer an academic space of exchange ideas and initiate the increase number of qualified article produced by postgraduate students, practitioners and academicians.

\section{Editorial Office}

Ruang Jurnal Shirkah

Lantai Dasar, Sayap Barat, Fakultas Ekonomi dan Bisnis Islam, IAIN Surakarta

Jln. Pandawa No. 1, Kartasura, Sukoharjo, Jawa Tengah Kode Pos. 57168

Phone (+62271) 781516 Fax: (+62271)782336

E-mail: shirkahiainsurakarta@gmail.com

Website: http://shirkah.or.id/ 



\section{Shirkah}

\section{Journal of Economics and Business}

Vol. 1, No. 3, September-December 2016

ISSN: 2503-4235 (p); 2503-4243 (e)

\section{Table of Contents}

\section{Articles}

Muhfiatun

The Effect of Sharia Monetary Policy and Financing Quality on Financial Performance in Sharia Banking

Roro Hindun

Izzul Fatchu Reza

Understanding Indonesian People Borrowing Money

from Banks and Non-Banking Institutions

M. Nur Rianto Al Arif

299

Monopoly and Ikhtikar in Islamic Economics

Trimulato

Sharia Bank Product Development through Mudhrabah Investment

Aida Nurul Hadiah

Financial Services Authority (OJK) Policy on Debt Proportion and Its Impact on the Profitability of DES Listed Companies in Indonesia

Statement of Financial Accounting Standard (PSAK)

No. 109 and Its Implementation in Several Zakat Management

Organizations in Malang, East Java 



\title{
Understanding Indonesian People Borrowing Money from Banks and Non-Banking Institutions
}

\author{
Roro Hindun \\ Sekolah Tinggi Ekonomi dan Bisnis Islam Al-Mubsin Yogyakarta \\ Izzul Fatchu Reza \\ Administrasi Publik, Universitas Lampung
}

\begin{abstract}
People's borrowing behaviours are influenced by the need to fulfil their basic needs which always change in maintaining their lifestyles. This research analyzes the tendency of Indonesians to borrowing money, either from banks or non-banking institutions. This research was carried out using quantitative data analysis with secondary data from the Indonesian Family Life Survey panel data versions 3 and 4. The data was analyzed using STATA 12.0 software. The results of the study show that the significant factors that affect people's behaviour in borrowing from either banks or non-banking institutions are amount of debt, assets, income, and location; while the insignificant factors are age, religion, and number of householders.
\end{abstract}

Keywords: money borrowing, loan behaviour, debt, IFLS, STATA

Human beings have many needs - that is, they have basic, secondary, and tertiary needs. In order to fulfill these needs, humans need instruments, i.e. trading tools and money. When money is insufficient to fulfill everyday needs, people borrow money. In the context of Indonesia society, they borrow money or other assets to fund their daily basic needs. Some use debt money as business equity. This kind of shortcut is normal. As an example, Indonesian youth borrow money to fulfil their secondary and tertiary needs, as in the purchase of mobile phones, laptops, and other gadgets (Husna, 2014). 
Loan either in term of money or property generally comes from formal and informal institutions. Formal institutions include banks and other non-bank financial institutions, like cooperations and baitul mal wattamwil. Informal institutions include borrowing from relatives or friends, neighborhood funds, and debtors. The decision of a household to borrow from banks or non-bank institutions shows the debt structure of Indonesian society in terms of the banking world or other non-bank financial institutions. Presently, commercial banks are rapidly marketting their debt products by easing requirements and repayments, and by offering low interest rates.

The diversity of credit suppliers nowadays means people can easily borrow money or goods. Thorough research regarding what determinants are most important in influencing preferences in people's borrowing behaviours in terms of whether they use conventional banking services or other non-bank finance institutions is much needed. This paper aims to find answer of a question: do loan amounts, total land assets owned, household income, education level, respondens age, respondens religion, number of household members, and the location of household (urban or rural) influence a household's decision to borrow from banks or non-bank institutions?

\section{The Concept of Borrowing}

Borrowing, or debt, literally in Arabic known as 'aroyah or i'arah, which originates from the word a'ara (أَعَار). Literally, 'ariyah or borrrowing is a right to utilize a thing received from other person without any retainer with the provision that the thing remains intact and at a time shall be returned to the owner. Allah, in Q.S. Al-Maidah (5) verse 12, states to give alms in Allah's way and the way that he blesses. In this verse, Allah asserts the allowance of borrowing something to another person with the 
intention to lend a borrowing to Allah, and in truth, Allah will be merciful of our sins and multiply the payment several times. In such conditions, Allah ordered that non-cash credit activities or money borrowing be done without diminishing the amount of the debt. Besides, there is also the proposition in the Prophet Muhammad's hadits, as mentioned Muhammad (in Muslich, 2010) that states, "According to Ibnu Mas'ud, this means that the Prophet Muhammad said: "There is no moslem giving credit to any other moslem twice, but he/she is like giving alms once" (HR. Ibnu Majah).

The propositions from the Alqur'an and Sunnah above show that generally Islam does not forbid the practice of borrowing, but rather suggests mutual relationships between moslems (Antonio, 1999). This is in line with the Islamic tenets, that moslems always tighten their ukhuwah islamiyyah relationships, by helping each other fulfill each others' needs, including in business. Debt in economics is a liability. Borrowing is money lent to someone that must be repaid. A borrower is a person who borrows money from another person (Rabbior, 2015, p. 131). There are two main reasons people borrow money. Firstly, because someone's income is higher than their standard needs. Therefore, he/she perceives that he/she can borrow. Secondly, because there is a rise in basic prices, for example, in the price of properties (Rabbior, 2015, p.132).

Brunnermeier and Sannikov (2011) suggest that credit or money borrowing occurs due to the imbalance of capital in society. People who have much money, but who are less productive, tend to invest their money in saving institutions, that is, either in banks or intermediary non-banking institutions. This intermediary institution then distributes the money to a more productive group in society, who generally have less capital. In short, the main theories that affect the borrowing preferences of households are the life cycle theory and the theory of the relationship between household borrowing and consumption price. 


\section{Life Cycle Theory of Borrowing}

The consumption lifecycle theory has a postulate that a household basically tries to maintain stable consumption patterns over the lifetime. Based on this theory, households are evaluated more on their smooth income than their current income (Campbell and Mankiw, 1990; Attanasio and Browning, 1995; DeJuan and Seater, 1999). The credit market can help households to fulfill their consumption objectives in various ways. For example, if a household expects a higher income in the future and also wants to consume more than it can afford, it can do so by borrowing. According to Andreou (2010), household borrowing is generally based on variabless which determine smooth income, such as age, education, gender, and employment.

Consumption price, which is mainly determined by the return on investment, is a key parameter for most inter-time borrowing preferences. The household borrows at this price when there is a wedge between deposit interest and borrowing cost. The consumption or investment is not always determined by a risk free return on a financial asset but more by a higher risk free return from paying down debt (Zinman, 2014). In line with this opinion, Moore (1997) also proposes that a dynamic interaction between debt limit and asset price can then be changed into an effective transmission, where the effect of the suspension is its continued existence, growth, and development into other sectors. From the borrowing aspect, he considers that disruption in technology or income distribution can produce continuous fluctuation and increase output and asset price.

Borrowing, also known as credit, is defined in Indonesian law in Act No. 14, 1967, chapter 1 and 2 which state: "Credit is the money provision or anything that is regarded similarly, based on the borrowing agreement between banks and other parties in which the borrower party must pay in full the debt after a period of time with certain interest" 
(Suhardjono, 2003). Furthermore, this definition was ammended in Act No. 7 regarding banking and was replaced by Act No. 10, 1998, which defines debt as, "money provision or bill as equal as it with an approval or borrowing agreement between the bank and other parties that obligates the borrower to pay in full the debt after a certain period with certain interest". Borrowing or debt can be classified based on the source or party that suggests the credit, i.e., formal or informal debt.

\section{Research Approach}

This research implements a quantitative empirical approach. The data provided in numbers is then analyzed into facts. Data in this research is taken from the survey conducted in households in Indonesia. The method used in the conclusions drawn on Indonesia are therefore deductive. The paradigm used in this research is positivistic, because this research attempts to find facts or causes of the social phenomena regarding borrowing from individuals' statements from the surveys. This research draws on a large sample, utilizing both quantitative data and quantitative analysis together with an econometric tool. This study uses secondary data derived from the Indonesian Family Life Survey (IFLS) volumes 3, (2000) and 4 (2007). IFLS is a longitudinal survey conducted by the RAND Cooperation (Research and Development) in Indonesia and is also referred to as the Indonesian Household Life Aspect Survey (SAKERTI).

The analysis in this research is conducted firstly using a descriptive method, which describes all of the variables related to borrowing behaviour. After these variables are described, an inferential method was conducted using ordinary least square statistical analysis, which is an improvement on the Gandimathi and Vanitha method (2010). The basic formula from Gandimathi and Vanitha is adjusted using an equation in the panel data (Reyna, 2007). In this research, a similar discriminant, consisting of socio- 
economic factors, is used to explain Indonesians' borrowing preferences in relation to banks and non-banks. With only two choices avaiable, banks or non-bank institutions, the dependent variable in this research is represented in the form of binary numbers, also called logit. Therefore, the statistical analysis used is logistic regression. The logit equation in this study is:

$$
P r_{i t}=\frac{1}{1+e^{-\left(\beta_{0}+\beta_{1} X_{1, i t}+\cdots+\beta_{k} X_{k, i t}+\gamma_{2} \mathrm{E}_{2}+\cdots+\gamma_{n} \mathrm{E}_{n}+u_{i t}\right)}}
$$

The model used in a logit regression must be appropriate or fulfill the goodness of fit $(\mathrm{GoF})$. A model is categorized as complying with GoF if there is congruity between the data entered into the model and the observed model. In logistic regression, the method to test fitness of the model generally uses the Pearson method, deviance and HosmerLemeshow. The degree of significance test of the model and the parameter in logistic regression uses statistical G-Test and Wald Test, respectively, for testing the model holistically and also for a partial test (individual). Both of these testing tools are identical with F-Test and T-Test using the Ordinary Least Square (OLS) (Hendayana, 2012). All models were tested to find out whether there are any effects from the freedom variables used in this model together with the respond variable. G-Test was conducted with degrees of confidence of $95 \%$. The formula for the G-Test was based on the hypotheses: $\mathrm{H}_{0}: \beta_{\mathrm{i}}=0 ;\left(\mathrm{H}_{\mathrm{i}}=\right.$ at least there is one $\left.\beta\right) \_\mathrm{i} \neq 0(\mathrm{i}=1,2,3, \ldots ., \mathrm{p})$

\section{Loan Behaviour}

Below is the table showing the total number of households in the IFLS in terms of borrowing behaviour and borrowing sources. 
Table 1. Borrower Data

\begin{tabular}{ccccc}
\hline $\begin{array}{c}\text { Year of } \\
\text { Borrowing }\end{array}$ & $\begin{array}{c}\text { Numbers of } \\
\text { Borrowers }\end{array}$ & $\begin{array}{c}\text { Borrowing } \\
\text { Source -Bank }\end{array}$ & $\begin{array}{c}\text { Borrowing Source } \\
\text {-Non-Bank }\end{array}$ & $\begin{array}{c}\text { Number of People } \\
\text { not Borrowing }\end{array}$ \\
\hline 2000 & 1124 & 747 & 377 & 51 \\
\hline 2007 & 2199 & 1335 & 796 & 10.785 \\
\hline Total & $\mathbf{3 3 2 3}$ & $\mathbf{2 0 8 2}$ & $\mathbf{1 1 7 3}$ & $\mathbf{1 0 . 8 3 6}$ \\
\hline
\end{tabular}

sources: inferred from IFLS 3 and 4 data

The result of logistic reggresion in the study model of demographic factors in borrowing preferences for banks or non-banks are described below.

The goodness of fit test run after getting the logistic regression model in STATA 12.0 yielded the results below.

Table 2. Result of Goodness of Fit Statistical Test

\begin{tabular}{|l|c|}
\hline Number of observations & 2935 \\
\hline $\begin{array}{l}\text { Number of covariate } \\
\text { patterns }\end{array}$ & 2935 \\
\hline Pearson chi2 (2938) & 442664,99 \\
\hline Pearson chi2 & 0,0000 \\
\hline
\end{tabular}

source: GoF calculation using STATA 12.0

In the model above, it is observed that the model fit is very good. It is showed from the observation total numbers and the same covariate pattern, 2935, and value of prob > chi2 given is less than the $\alpha$ value. Thereby, the $\mathrm{H}_{0}$ result is accepted, which means that this logit model is an appropriate fit.

The significance test is conducted by observing at $G$ value or $\log$ likelihood of $-1648,98$ with Prob.>chi2 value of 0,0000 or less than 0,05 . The Wald test described from the $\mathrm{Z}$ value model of 6,41 with a $\mathrm{p}$-value of 0,0000 , therefore $\mathrm{H}_{0}$ is rejected or $\mathrm{H}_{1}$ is accepted. Hence, the significance test confers a result of influence between the regression model design as 
a whole and the behaviour of people borrowing money from bank or non-banks. The result of the regression above produced the log likelihood of $-1648,98$ with Prob>chi2 value of 0.0000 . With the value given, $0,0000<0,05$, hence the Ho can be rejected or $\mathrm{H}_{1}$ is accepted. Because this $p$-value is far below the degree of significance, it can be concluded that this logistic regression model is holistically fit, and characterized by at least one $\beta$ parameter which is not equal to zero with a significance degree of $5 \%$.

From the result of the regression, amount of debt has a very significant influence on decisions related to borrowing sources for Indonesians. The value of $\mathrm{z}$ given is 13,73 with $\mathrm{p}$-value of 0,00 . The odds ratio coefficient is 1 , which means that the likelihood of households borrowing from banks is 1 unit higher if the amount of debt is big, rather than if they borrow with less amount of debt. From the interpretation of the relation between asset and preference in Indonesian borrowing behaviour, there is a positive linkage with coefficient $\mathrm{z}$ is 3,13 in the degree of p-value 0,002 . The odds ratio coefficient is 1 , which means that the opportunity of a household with more assets, will increase the opportunity of borrowing in their bank 1 time more than for those with fewer assets.

Looking at the income variable, the relation is negative, with $\mathrm{z}$ coefficient $\mathrm{z}=2,09$ and $\mathrm{p}$-value of 0,035 . The value of odds ratio produced means that if household income is 1 unit higher, the opportunity of the household to borrow from a bank will decrease byl unit and be reversed. The analysis of logistic regression in education shows the variable with $\mathrm{z}$ value of 2,51 and p-value showed 0,036 . The interpretation of odds ratio generated is that the higher the education of the head of the household, the higher the opportunity to borrow from banks, by 1,04 unit.

Age variable shows a less significant effect in its relation to household preferences in borrowing from banks, with z-value of 1,93 and p-value of 0,054 . The numbers of household members shows an 
insignificant influence on onopportunity of households to borrow from banks or non-banks, with z-value of 0,51 and which generates a $p$-value of 0,609 . In the religion variable, the z-value test generated is $-1,08$ with p-value of 0,281 , thereby this variable does not significantly influence the intention of a household to borrow from banks or non-bank institutions.

Regarding the location element, i.e. the dummy urban or rural has a significant influence and marked positive with the decision of households to borrowing from banks or non-bank institutions. From the z-test value of 3,55 , this variable generates a p-value of 0,00 . The odds-ratio coefficient of 0,72 means that the opportunity of a household to borrow from a bank is 0,72 times higher if a household is located in a rural area as opposed to respondents who live in the city with a significant influence.

\section{Analysis of Logistic Regression Comparison Between}

Below is the logistic regression result ran on the model of IFLS money borrowing in the year 2000 .

\section{Table 3. Result of Logistic Regression in 2000}

\begin{tabular}{lcc}
\hline & $(1)$ & $(2)$ \\
VARIABLES & Logit coeff & Odds ratio \\
\hline & & \\
Source & & \\
Total borrowed & $4.57^{* * *}$ & $1.000^{* * *}$ \\
& $(4.38)$ & $(4.38)$ \\
Assets & $2.84^{* * *}$ & $1.000^{* * *}$ \\
& $(9.74)$ & $(9.74)$ \\
Income & $-1.66^{*}$ & $1.000^{*}$ \\
& $(9.42)$ & $(9.42)$ \\
Education & -0.0207 & 0.979
\end{tabular}




$\begin{array}{lcc} & (0.0241) & (0.0236) \\ \text { Age } & 0.00125 & 1.001 \\ & (0.00199) & (0.00199) \\ \text { Total ART } & 0.00763 & 1.008 \\ & (0.0331) & (0.0333) \\ \text { Religion } & -0.475^{* *} & 0.622^{* *} \\ & (0.230) & (0.143) \\ \text { Urban/Rurual } & -0.415^{* * *} & 0.660^{* * *} \\ \text { Constant } & (0.158) & (0.104) \\ & -0.812^{* *} & 0.444^{* *} \\ & (0.360) & (0.160)\end{array}$

Observations

1,026

1,026

Standard errors in parentheses *** $\mathrm{p}<0.01,{ }^{* *} \mathrm{p}<0.05,{ }^{*} \mathrm{p}<0.1$

Source: logistic regression calculation using STATA 12.

The result of regression in 2000 is as shown below.

Table 4. Logistic Regression Result, 2007

\begin{tabular}{lcc}
\hline & $(1)$ & $(2)$ \\
VARIABLES & Logit coeff & Odds ratio \\
\hline
\end{tabular}

Source

Total borrowed

$\begin{array}{cc}9.64^{* * *} & 1.000^{* * *} \\ (7.96) & (7.96) \\ 9.25^{* *} & 1.000^{* *} \\ (4.34) & (4.34) \\ -3.08 & 1.000 \\ (2.47) & (2.47)\end{array}$

Vol. 1 No. 3, September - December 2016 


$\begin{array}{lcc}\text { Education } & 0.0544^{* * *} & 1.056^{* * *} \\ & (0.0176) & (0.0186) \\ \text { Age } & 0.00680^{* *} & 1.007^{* *} \\ & (0.00304) & (0.00306) \\ \text { Total ART } & 0.00855 & 1.009 \\ & (0.0195) & (0.0197) \\ \text { Religion } & 0.291^{*} & 1.338^{*} \\ & (0.166) & (0.222) \\ \text { Urban/Rural } & -0.238^{* *} & 0.788^{* *} \\ & (0.113) & (0.0892) \\ \text { Constant } & -2.065^{* * *} & 0.127^{* * *} \\ & (0.269) & (0.0342)\end{array}$

Observations

1,923

1,923

Standard errors in parentheses ${ }^{* * *} \mathrm{p}<0.01,{ }^{* *} \mathrm{p}<0.05,{ }^{*} \mathrm{p}<0.1$

In 2000, the result of the STATA data showed that the model produced is convergence not achieved. With only five iterations, the result yielded that the significance variables important to whether households borrow from either banks or non-bank institutions are the amount of debt, total assets, religion, and location. While in 2007, the result of the regression showed that amount of debt, assets, education, age, and location sigificantly influence borrowing from banks or non-bank institutions.

\section{Conclusion}

The significant factors influencing preference in borrowing money from banks or non-bank institutions for Indonesian people are amount of debt, assets, income, and location (urban or rural). Meanwhile, the factors of age, religion, and household members were insignificant. From 
the regression result in 2000 the significant variables to a household borrowing from banks or non-bank institutions were amount of debt, assets, religion, and location. While in 2007, the regression result showed that the significant influences were amount of debt, assets, education, age, and location.

It is important that there is depth to socialization from the government and ministry of finance regarding the details of money borrowing, to ensure that people have a good understanding of the appropriate money borrowing sources particular to their needs and contexts. Economically vulnerable members of society with small assets must be socially protected and given special credit access, due to their lack of access to loans. 


\section{References}

Andreou, S. N. (2011). The Borrowing Behaviour of Households: Evidence from the Cyprus Family Expenditure Surveys. Cyprus Economic Policy Review, 5 (2), 57-83.

Antonio, M Syafi'i. (1999). Bank Syariah Bagi Banker dan Praktisi Keuangan. Jakarta: Gema Insani Press.

Attanasio, O. P., \& M. B. (1995). Consumption Over The Life Cycle And Over The Business Cycle. American Economic Review, 85, 1118-1137.

Brunneimeier, M. K., \& Sannikov, Y. (2011). The Theory of Money. Working Paper. Princeton University.

Campbell, J. N., \& Mankiw, G. (1990). Permanent Income, Current Income, and Consumption. Journal of Business \& Economic Statistics, 8 (3), 265-279.

DeJuan, J. \& Seater, J. (1999). The Permanent Income Hypothesis: Evidence from the Consumer Expenditure Survey. Journal of Monetary Economics, 43, 351-376.

Gandhimathi, S., \& Vanitha, S. (2010). Determinants of Borrowing Behaviour of Farmers-A Comparative Study of Commercial and Cooperative Banks. Agricultural Economics Research Review, 23, January-June 2010, 157-164.

Hendayana, R., A. Djauhari, A. Gozali A.N., E. Syaefulloh, \& R.S. Hutomo. (2009). Disain Model Percepatan Adopsi Inovasi Teknologi Program Unggulan Badan Litbang Pertanian. Laporan Hasil Penelitian. Kerjasama Menristek - Badan Litbang Pertanian.

Husna, M. (2014). Perilaku Konsumen Mahasiswa. Skripsi. Bandung: Universitas Pendidikan Indonesia.

Moore, John. (2007). Stable Sets and Steady Wages. Scottish Journal of Political Economy. Scottish Economic Society, 54 (5), pp. 721-730, November. 
Muslich, Ahmad Wardi. (2010). Fiqh Muamalat. Jakarta: Amzah.

Rabbior. (2015). Money and Youth: A Guide to Financial Literacy. Canada: Canadian Foundation for Economic Education.

RAND IFLS. (2013). IFLS EAST 2012 Available from SurveyMETER. http:// www.rand.org/labor/FLS/IFLS.html. Accessed 20 February 2015.

Suhardjono. (2003). Manajemen Perkreditan Usaha Kecil dan Menengah. Yogyakarta. UPP AMP YKPN. 
Vol. 1 No. 3, September - December 2016 